\title{
Analysis on Players' Playing Skills During the National Volleyball League (Proliga) 2016
}

\author{
Waluyo $^{1}$, Soegiyanto ${ }^{2}$, Hari Setijono ${ }^{3}$, Sulaiman ${ }^{4}$ \\ ${ }^{1,2,4}$ Graduate School in Sport Education, Universitas Negeri Semarang, Indonesia \\ ${ }^{3}$ Faculty of Sport Science, Universitas Negeri Surabaya, Indonesia \\ ${ }^{1}$ Corresponding email: waluyounsri@yahoo.com
}

\begin{abstract}
The setback in our national-level volleyball teams is caused not only by factors of guidance and competitions. Playing skill also constitute a basic factor for producing maximum achievements. Therefore, this research was intended to analyze the skills of female Indonesian national-level volleyball teams championing the Proliga final four. This research used combination methods and collected the statistical data on the spiking, blocking, serving and receiving skills. The data were then analyzed statistically and descriptively for drawing the conclusions. The subjects for this research were 50 female volleyball players participating in the final four, 2016. For collecting the sample, this research used the technique of purposive sampling. The instrument used was VIS (Volleyball Information System). The results show that the best spiking skills were dominated by Gersik Petrokimia $(52,87 \%)$, the best blocking skills were dominated by Jakarta Pertamina Energi $(52,94 \%)$, the best serving skills were dominated by Jakarta Elektrik PLN $(76,82 \%)$ and the best receiving skills were dominated by Jakarta Pertamina Energi $(93,60 \%)$. The results from such prediction might then be used for developing the strategies for winning the competitions, level of sports professional achievement and level of students.
\end{abstract}

Keywords: Pro Liga, Volleyball, Spiking, Blocking, Serving and Receiving

\section{Introduction}

The game of volleyball has characteristics in the form of motion skills, social values, competitive values, thinking skills, legal order and rules and physical fitness. The basic skills of motion in volleyball are vertical jump, reach reach and block jump reach. Anthropometric characteristics have a great influence on an athlete's performance (Nasuka, 2017).

The achievements of Indonesian nationallevel female volleyball teams keep rising and falling. The statement by the Central Body for Indonesian Volleyball Union (PP PBVSI) acknowledges that Indonesian achievement in volleyball has not been maximum, particularly for the female teams, that these female teams could not do much even in Asian level (Republika, 2015).

In sports achievement should have a definite goal, have the principle of exercise and influence on the sport that followed, that there is influence in everyday life. The purpose of the exercise is to increase the maximum performance, improvement of health and improvement of physical condition (Purwanto, 2013).

Some things to consider in the game of volleyball in order to achieve the maximum understanding of basic techniques and can do it well. There are several basic techniques in the game bolavoli such as: spike, service, receive and block (Dharmawan, 2016).

Proliga championship, which is held once a year, constitutes an elite-level competition in volleyball. Proliga championships are also used for selecting the best players who might then be positioned in the country's national team. The Proliga final four was a situation where 4 best teams existed after defeating many other teams. The Proliga volleyball competitions for female teams, which lasted for about one week, tended to be unsatisfactory. This was in accord with the Chief of KONI (PBVSI), Rita Subowo, who referred to the setback in the item of volleyball. The setback relates to guidance, competition and achievement. Teams possessing better playing skills would win, but any error or mistake done while performing the skills might have higher risk for losing than such technical errors as imperfect spiking, blocking, serving or receiving.

The playing skill of the female nationallevel volleyball teams of this country should be evaluated first and then improved. This research was intended to analyze the skills of female Indonesian national-level volleyball teams championing the Proliga final four. The skill items were spiking, blocking, serving and receiving. The findings of the analyses might 
then be used by volleyball teams as information for predicting both the strength and weakness of the potential opponents. The results from such prediction might then be used for developing the strategies for winning the games.

\section{Methods}

This research was conducted during the first session of Proliga 2016 for female volleyball teams in GOR Citra Arena (Sport Stadion), in Bandung, West Java. The sampled subjects were 50 female players from 4 teams participating in the final four. The sample was taken using the technique of purposive sampling. First, we recorded the skills of each player in performing the spiking, blocking, serving and receiving. For this purpose, we used the necessary equipment consisting of such items as cameras, tripods, laptops and software dartfish version 5.5 team pro. After the recording processes were over, we analyzed the total scores for identifying "high group" and "low group" from the whole population. The statistical data from the PBSVI's statistical team consisted of terminal actions in spiking, timing in blocking, accuracies in serving, and continuity of actions after receiving. These data were then analyzed and described using SPSS 20 software in order to confirm the validity of our groupings.

\section{Results and Discussions}

Based on the data collected from the Proliga final four (JEP/Jakarta Electric of PLN, GPK/Gresik Petro Kimia, JPE/Jakarta Pertamina Energy and JPP/Jakarta PGN Popsivo), the spiking, blocking, serving and receiving skills of the female volleyball teams could be found out (Figures 1, 2 and 3). The abilities of the female teams in the 4 types of skills can be detailed as below.

Female Volleyball team of JEP (Jakarta

Electric) versus GPK (Gresik Petrokimia)

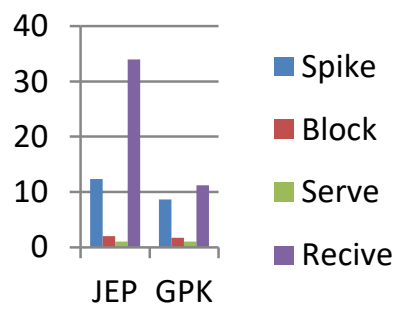

Figure 1. Mean scores for the executed Spiking, Blocking, Serving and Receiving skills
From Figure 1, it can be seen that the skills of JEP team in executing the spiking, blocking and receiving techniques were higher than those of GPK. In serving skill, the two teams are about the same. In this case, JEP won by 3 to 1 by means of superiority in the three types of skills.

Female Volleyball team of JEP versus JPE (Jakarta Petro Kimia Energy)

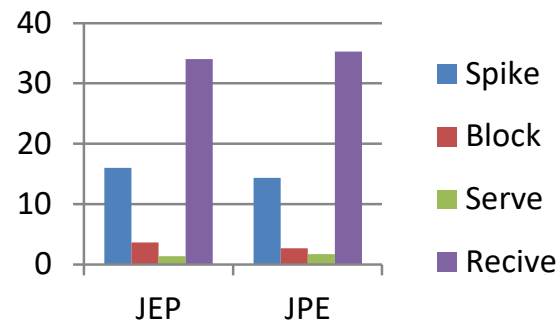

Figure 2. Mean scores for the executed Spiking, Blocking, Serving and Receiving skills

Figure 2 shows that the receiving and serving skills of JEP were lower than those of JPE. In addition to the fact that different teams make different intensities of errors during the matches, however, the successful executions of spiking and blocking skills by JEP were higher than those executed by JPE, that JEP managed to win the match by 3 to 2 . It then means that spiking and blocking skills in the match had produced the winning points while the serving and receiving skills did not.

Female Volleyball team of JEP versus JPP (Jakarta PGN Popsivo)

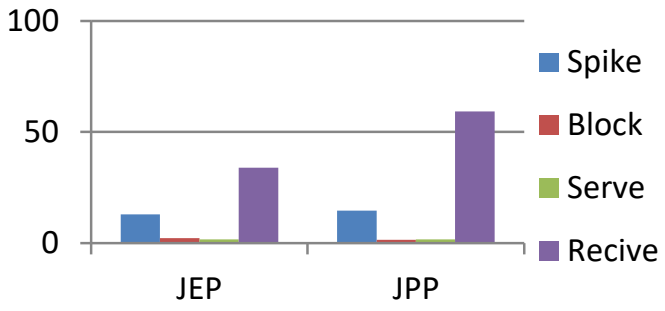

Figure 3. Mean scores for the executed Spiking, Blocking, Serving and Receiving skills

Figure 3 shows that JPP team is much more superior in spiking and receiving skills than JEP, which is more superior only in blocking skill. However, some players in JPP made so many errors (up to 28 errors in total) that the blocking executions by JEP lead it to win the match by 3 to 1 . This analysis might 
inspire other volleyball teams that blocking skill could be very important for winning the match.

The results from executed skills in 3 matches

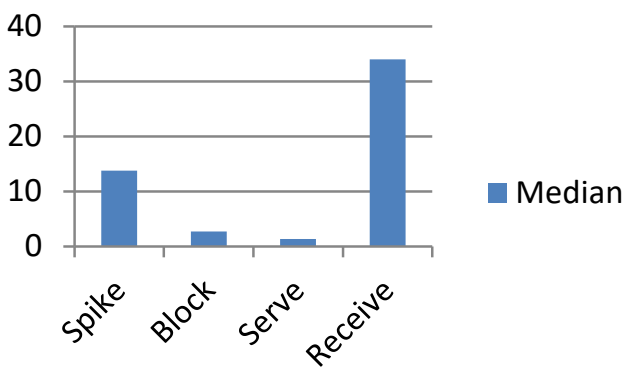

Figure 4. Total skills executed by JEP in 3 matches

Figure 4 shows the total of executed spiking, blocking, serving and receiving skills by JEP. Out of 565 executed skills, 124 spiking, 22 blocking and 11 serving produced scoring points, and 408 receiving saved the team from losing the scoring points.

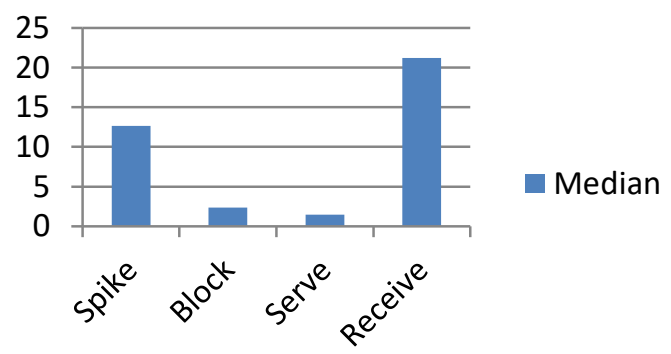

Figure 5. Total skills executed by GPK in 3 matches

Figure 5 shows the total of executed spiking, blocking, serving and receiving skills by GPK. Out of 466 executed skills, 114 spiking, 21 blocking and 13 serving produced scoring points, and 318 receiving saved the team from losing the scoring points.

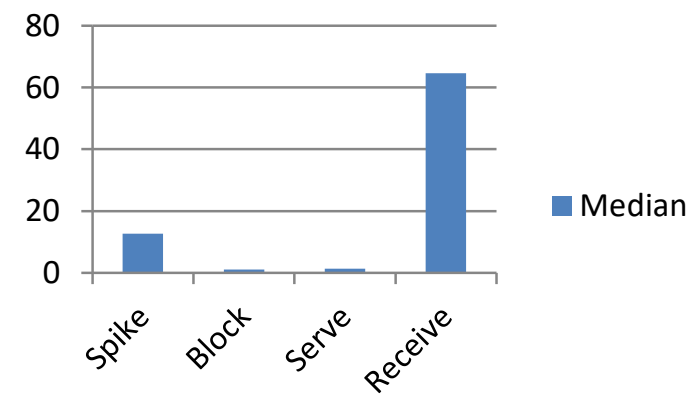

Figure 6. Total skills executed by JPE in 3 matches
Figure 6 shows the total of executed spiking, blocking, serving and receiving skills by JPE. Out of 571 executed skills, 127 spiking, 26 blocking and 15 serving produced scoring points, and 403 receiving saved the team from losing the scoring points.

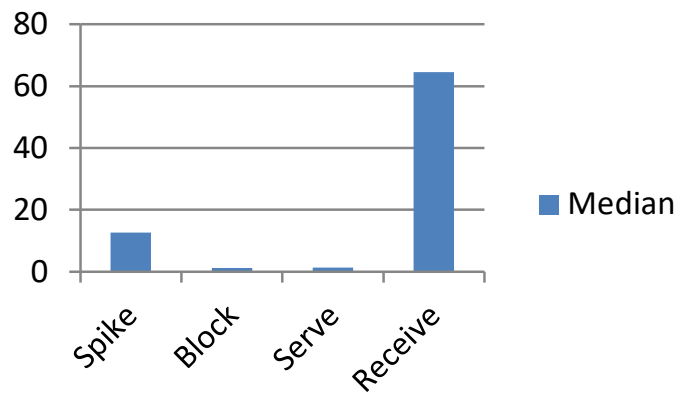

Figure 7. Total skills executed by JPP in 3 matches

Figure 7 shows the total of executed spiking, blocking, serving and receiving skills by JPP. Out of 848 executed skills, 114 spiking, 9 blocking and 12 serving produced scoring points, and 710 receiving saved the team from losing the scoring points.

\section{Discussions}

Based on the analyses, the successful executions of spiking, blocking, serving and receiving skills can be described as below.

\section{Spiking Skill}

In spiking executions, female volleyball players in the final four made many errors resulting in losing points for their own teams. They were careless in developing the attacks and did not try to carefully learn the direction of the ball blocked by the opponent. (Silva et al., 2014) pointed out that a team making the fewest errors would be successful in the match. A similar view had been proposed by (Ackerman, 2014) who said that spiking is the most energized action in a volleyball match. Spiking is a skill for which every young player wants to learn.

Depending on the temporal time needed or on the potential spiking angles, make 3 or 4 steps forward. Attacking the opponent by means of spiking after receiving action has a great effect on winning than serving and blocking actions which have only little contribution for winning the match (Patsiaoras et al., 2010) 


\section{Blocking Skill}

(Ahmadi, 2007) pointed out that blocking technique constitutes the main defensive means for neutralizing the opponent attacks. Considering only the moving aspect, blocking is not difficult to learn. However, the percentage of successful blocking is relatively small, since the direction of the incoming ball is controlled by the player who spikes it. The successfulness of a block is also determined by the height of the jump and by the reaches of the hands that will block the ball. It means that blocking skill constitutes a vital aspect for any game (Ackerman, 2014).

Blocking might be not as important as serving, passing, setting or digging skill, but Walsh Jennings in Ackerman J (2014) pointed out that a team having a high ability in blocking is a team that is difficult to defeat. (Sarumpaet, 2013) pointed out that blocking constitutes an effective way for defending the team from smashes. Blocking is executed by jumping upward as high as possible for sending the incoming ball back to the opponent's field.

\section{Serving Skill}

In volleyball, serving constitutes the main capital for producing score points. Therefore, volleyball players should be fully focused in doing the serves, that maximum results might be produced. The mistakes commonly done by volleyball trainees relate to the positions of body, legs or arms or all the three. For example, the serving arm lacks of swinging force that the ball flies with a weak force, the ball is thrown upward imperfectly (before being served) that it is not well controlled by the server him/herself, or the server is not well focused on the ball that the ball flies to the wrong direction or to the direction that is not intended by the server.

\section{Receiving Skill}

Receiving also constitutes an initial step for developing the next attack that might produce scoring points. High skill in receiving is very necessary in order that the ball can be passed to the setter who will then pass it to the spiker.

The statistical data showed that during the Proliga, nearly all players executed receiving actions. However, there were many players who made errors in the receiving actions. Skill errors (errors in the movements of the body parts during the execution of receiving actions) occurred more commonly than technical errors (Busca \& Febrere, 2012). The action of receiving could mean an indirect producer of scoring points, while spiking, blocking and serving mean direct producers of scores (Marcelino et al., 2010). In order that a receive can be maximum (Kenny \& Gregory, 2006) recommended a basic formation of $\mathrm{W}$ character or a five players system.

\section{Conclusions}

JEP became the champion in the Proliga final four, since it had good spiking, blocking, serving and receiving skills. The statistical data showed that spiking, blocking and receiving were the skills which determined the winnings. Spiking and blocking are effective for producing points. In order to be a champion, any team should develop good playing and technical skills. Trying to make as a few mistakes as possible in the technique of playing might give you an opportunity to win.

\section{References}

Ackerman, J. 2014. Girls volleyball. Minnesota: ABDO Publishing Company

Ahmadi. 2007. Panduan Olahraga Bolavi. Surakarta: Era Pustika Utama

Busca, B. \& Febrer, J. 2012. Temporal fight between the middle blocker and the setter in high level volleyball. Rev. Int. Med. Cienc. Act. Fis. Deporte, 12(46): 313-327.

Dharmawan, G. 2016. Pengaruh Side Hop dan Box Jump terhadap Daya Ledak Otot Tungkai Ekstrakurikuler Bola Voli. EJournal Ilmu Keolahragaan Universitas Pendidikan Ganesha Jurusan Ilmu Keolahragaan . 1 (3) : $1-12$.

Kenny, B \& Gregory, C. 2006. Volleyball step to success. Champaign: Human Kinetics

Marcelino, R., Mesquita, I., \& Sampaio, J. 2010. Efficacy of the volleyball game actions related to the quality of opposition. The Open Sports Sciences Journal, 3, 34-35.

Nasuka. 2017. Hubungan Panjang Lengan dan Panjang Tungkai dengan Kemampuan Vertical Jump, Spike Jump Reach dan Block Jump Reach Remaja Putra. Jurnal Media Ilmu Keolahragaan Indonesia. 7 (1): $36-38$. 
Patsiaouras, A. Moustakidis, A., Charitonidis, K., \& Kokaridas, 2010. Volleyball technical skills as winning and qualification factors during Olympic games 2008.

Purwanto, D. 2013. Survey Kondisi Fisik Dan Keterampilan Teknik Dasar Bola Voli Pada Klub Bola Voli Putri Bravo
Banjarnegara Tahun 2012. Journal of Physical Education, Sport, Health and Recreation. 2 (4) : $319-321$.

Republika. 2015. PBVSI: Prestasi Voli Indonesia Belum Maksimal”. Republika.co.id.

Sarumpaet. 2013. Buku Permainan Besar. Padang: Depdikbud.. 